\title{
Clinical changes in sodium monoiodoacetate-induced stifle osteoarthritis model in dogs
}

\author{
NV Goranov \\ Department of Veterinary Surgery, \\ Faculty of Veterinary Medicine, Stara Zagora, Bulgaria \\ E-mail: nickgoranov@yahoo.com \\ Received: 06-10-2011, Accepted: 12-10-2011, Published Online: 15-12-2011 \\ doi: $10.5455 /$ vetworld.2012.138-144
}

\begin{abstract}
In six dogs, experimental model of osteoarthritis (OA) was reproduced by intraarticular injection of sodium monoiodoacetate (MIA) in left stifle joints. Contralateral joints served as control. The clinical status and some goniometric parameters were monitored before MIA introduction and at post injection days 30, 60 and 105 . The results showed convincingly that the used experimental chemical OA model reproduced successfully the disease in canine stifle joints. The studied clinical indices correlated with the severity of disease.
\end{abstract}

Key words: dogs, stifle joint, sodium monoiodoacetate, osteoarthritis

\section{To cite this article :}

Goranov NV (2012) Clinical changes in sodium monoiodoacetate-induced stifle osteoarthritis model in dogs, Vet. World. 5(3): 138-144, doi: 10.5455/vetworld.2012.138-144.

\section{I ntroduction}

Osteoarthritis (OA) is a degenerative articular cartilage disease encountered in all mammals, birds and men (Lipowitz, 1993). Ehrlich (2003) and Haima (2005) describe it as a "wear-andtear" process, while Bennett (1990) defines OA as the final stage of a prolonged accumulation of biochemical disorders, hence, as adaptation of the joint to abnormal stress. Gardner (1994); Grainger \& Cicuttini (2004) support the hypothesis for the multifactorial etiology of OA resulting in cartilage loss, bone remodeling, pain, effusion and inactivity.

The incidence of degenerative joint conditions in dogs is about $78 \%$, with increasing share of primary OA with age (May, 1994). According to Anderson (1994) and Vasseur (1993), in small animals, the stifle joint is the most commonly affected (more than $20 \%$ of all OA cases), a substantial part of alterations being bilateral (Tirgari \& Vaughan, 1975).

The experimental reproduction of OA is of both scientific and applied importance. Sometimes, this is the only means to confirm a working hypothesis. Orthopaedics uses frequently in vivo experimental animal models (Bendele, 2001; Murray, 2002). The reproduction of all disorders and symptoms of OA is however challenging, so a model possessing the most important signs of natural disease and that could be reproduced, is good enough for the purpose of research (Brandt, 2002; Carlson, 2005). The interest towards reproduction of $\mathrm{OA}$ of the knee is due to its anatomical features and the increasing prevalence of natural degenerative events (Bendele, 2001; Carlson, 2005). The numerous existing experimental models of OA are classified by Witter (1999) and Schaller et al. (2005).

The metabolic inhibitor sodium monoiodoacetate (MIA) destructs the joint cartilage by blocking glyceraldehyde-3-phosphate dehydrogenase in chondrocytes and inhibition of glycolysis. The rapid depletion of ATP results in cellular death. The number of cells is progressively reduced, the synthesis of proteoglycans for the articular matrix is stopped (Kalbhen, 1987; Van 
der Kraan et al. 1989). MIA-induced degenerative processes, typical for natural OA, appear within 6 to 8 weeks (Kalbhen \& Blum, 1977; Janusz et al. 2001; Guzman et al. 2003). The time of occurrence of changes and the used MIA doses are very different. Fourteen weeks after two intraarticular injections of $0.6 \mathrm{mg}$ MIA in the stifle joints of hens, Kalbhen \& Jansen (1990) detected radiological and gross anatomical changes. Gencosmanoglu et al. (2001) have achieved a chondrotoxic effect in rats after 8 weekly injections of $1 \mathrm{mg}$ MIA. Permanent histological injuries were reported to occur after 2 to 8 weeks of application of 1 to $4 \mathrm{mg}$ MIA in rats; they were progressive and similar to OA lesions in humans (Saied et al. 1997; Guinamp et al. 1997; Bove et al. 2003; Guzman et al. 2003). The rat OA model (2 mg MIA) was found useful for monitoring of chronic OA pain over 10 weeks (Combe et al. 2004). In mice, Boileau et al. (2004) have used a single dose of $0.1 \mathrm{mg}$ MIA. The histological changes were detected 7-14 days later.

In rabbits, the described events occurred until the $12^{\text {th }}$ week (Regling et al. 1989), with correlative changes in alkaline phosphatase and lactate dehydrogenase activities (Horn et al. 1988). Gustafson et al. (1992) have evaluated the changes in equine carpal joints with regard to the applied MIA dose as mild $(0.09 \mathrm{mg} / \mathrm{kg})$, moderate $(0.12 \mathrm{mg} / \mathrm{kg})$, and severe $(0.16 \mathrm{mg} / \mathrm{kg})$ after a 12-week period. Moreover, it turned out that high MIA doses $(60-100 \mathrm{mg} / \mathrm{ml}$ in $2 \mathrm{ml})$ were able to provoke a chemical arthrodesis of equine tarsal joint after 13-51 months (Penraat et al. 2000; Bohanon, 1995). Therefore, the MIA dose and the number of intraarticular applications were essential for the reproduction of the generative process.

Stobie et al. (1994) were the only researchers having applied twice MIA in dogs at doses of $0.375 \mathrm{mg} / \mathrm{kg}$ and $0.500 \mathrm{mg} / \mathrm{kg}$ MIA at a 2 -week interval, but the result was an insignificant lameness without permanently affected locomotion and biochemical profile until the $12^{\text {th }}$ post injection week. The authors did not support their findings with histological evidence, but nevertheless they suggested that most probably, higher doses and/or multiple injections would result in more consistent $\mathrm{OA}$ changes in this animal species.

The clinical evaluation of lameness, pain, joint effusion and stifle joint motility is subjective (Budsberg \& Thomas, 2006). Therefore, several authors (Cross et al., 1997; Grisneaux et al., 1999; Budsberg et al., 1999) introduced scoring systems for cumulative assessment of these parameters. The range of motion is an objective although non-specific parameter, while goniometry is a non-invasive method for quantitative estimation of the range of motion by measurement of specific angles formed by bones (Lipowitz, 1993; Jaegger et al., 2002). They could be also used to assess the efficacy of therapy (Crook et al., 2007). These measurements are routinely performed in men, but literature data about dogs are very limited (Millis \& Lavine, 1997; Jaegger et al. (2002).

The purpose of the present study was to attempt to reproduce experimentally stifle osteoarthritis in dogs by means of intraarticular administration of sodium monoiodoacetate and to evaluate the success or failure of the model by means of gait and pain analyses.

\section{Materials and methods}

Experimental animals: Six clinically healthy mongrel dogs from both sexes were used (body weight $15 \pm 2 \mathrm{~kg}$ ). They were housed indoor in individual boxes and had free access to drinking water and dry canine food for maintenance. The experiment was approved by the Committee on Animal Experimentation at the Trakia University, Stara Zagora, Bulgaria and was performed in strict compliance with animal welfare regulations (Directive 86/609/EEC).

Reproduction of osteoarthritis: In the left stifle joint of each dog, ten intraarticular injections of sodium monoiodoacetate (MIA) (MERCK \# S05800 228) were performed once weekly at doses of $0.12,0.14,0.16,0.26,0.36,0.96,1.28$, $3.00,5.00$ and $10.00 \mathrm{mg} / \mathrm{kg}$ in $1 \mathrm{ml} 0.9 \%$ saline solution. The right joint served as control. The clinical parameters were monitored on days 0,30 , 60 and 105. 
Clinical evaluation and goniometric analysis: Three clinical scoring systems - according to Grisneaux et al. (1999), Cross et al. (1997) and Budsberg et al. (1999), originally used for drug therapy efficacy evaluation, were parallelly used for gait, behaviour and pain analysis (Tables 1,2,3).

Table-1. Criteria for pain and behaviour evaluation of dogs with osteoarthritis (Grisneaux et al., 1999).

\begin{tabular}{|c|c|c|}
\hline Parameter & Score & Clinical sign \\
\hline Behaviour & $\begin{array}{l}1 \\
2 \\
3 \\
4 \\
5\end{array}$ & $\begin{array}{l}\text { Apathetic or indifferent } \\
\text { Friendly } \\
\text { Nervous, submissive behaviour } \\
\text { Very nervous, tries to move away } \\
\text { Aggressive }\end{array}$ \\
\hline $\begin{array}{l}\text { Compliance } \\
\text { with restraint }\end{array}$ & $\begin{array}{l}0 \\
1 \\
2 \\
3\end{array}$ & $\begin{array}{l}\text { No objection } \\
\text { Recognizes manipulations, no complaint } \\
\text { Objects but does not try to bite } \\
\text { Tries to bites and struggles }\end{array}$ \\
\hline Heart rate & $\begin{array}{l}0 \\
1 \\
2 \\
3\end{array}$ & $\begin{array}{l}0 \text { to } 10 \% \text { greater than normal } \\
11 \text { to } 30 \% \text { greater than normal } \\
31 \text { to } 50 \% \text { greater than normal } \\
>50 \% \text { greater than normal }\end{array}$ \\
\hline $\begin{array}{l}\text { Respiratory } \\
\text { rate }\end{array}$ & $\begin{array}{l}0 \\
1 \\
2\end{array}$ & $\begin{array}{l}\text { Normal } \\
\text { Mild abdominal assistance } \\
\text { Marked abdominal assistance }\end{array}$ \\
\hline Vocalization & $\begin{array}{l}0 \\
1 \\
2\end{array}$ & $\begin{array}{l}\text { No crying } \\
\text { Crying but responds to calm voice } \\
\text { Crying but does not respond to calm voice }\end{array}$ \\
\hline Agitation & $\begin{array}{l}0 \\
1 \\
2 \\
3\end{array}$ & $\begin{array}{l}\text { Asleep or calm } \\
\text { Mild agitation } \\
\text { Moderate agitation } \\
\text { Severe agitation }\end{array}$ \\
\hline $\begin{array}{l}\text { Response to } \\
\text { manipulation }\end{array}$ & $\begin{array}{l}0 \\
1 \\
2 \\
3\end{array}$ & $\begin{array}{l}\text { No response } \\
\text { Minimal response } \\
\text { Turns head toward site, slight vocalization } \\
\text { Turns head to bite, howls }\end{array}$ \\
\hline
\end{tabular}

Table-2. Kinetic gait analysis system for clinical evaluation of lameness, pain and joint effusion of knee osteoarthritis in dogs (Cross et al., 1997)

\begin{tabular}{|c|c|c|}
\hline Parameter & Score & Clinical sign \\
\hline Standing & 1 & Normal weight-bearing \\
\hline \multirow[t]{3}{*}{ lameness } & 2 & Partial weight-bearing \\
\hline & 3 & Intermittent toe touching \\
\hline & 4 & No weight-bearing \\
\hline Trotting & 1 & Normal weight-bearing \\
\hline \multirow[t]{3}{*}{ lameness } & 2 & Marked lameness with partial weight-bearing \\
\hline & 3 & Marked lameness with intermittent toe touching \\
\hline & 4 & No weight-bearing \\
\hline \multirow{4}{*}{ Pain response } & 1 & Absence of pain and response \\
\hline & 2 & $\begin{array}{l}\text { Slight pain, allowing manipulations of the } \\
\text { limb within the normal range of motility, } \\
\text { manifested by turning the head and pulling } \\
\text { the limb away }\end{array}$ \\
\hline & 3 & $\begin{array}{l}\text { Moderate pain, not allowing manipulations of } \\
\text { the limb within the normal range of motility, } \\
\text { manifested as described for score } 2\end{array}$ \\
\hline & 4 & $\begin{array}{l}\text { Significant pain, not allowing manipulations } \\
\text { of the limb Joint }\end{array}$ \\
\hline \multirow[t]{4}{*}{ effusion } & 1 & $\begin{array}{l}\text { Normal - palpatory compression upon the } \\
\text { patellar ligament }\end{array}$ \\
\hline & 2 & $\begin{array}{l}\text { Weak - slight increase, the patellar ligament } \\
\text { is palpated }\end{array}$ \\
\hline & 3 & $\begin{array}{l}\text { Moderate - marked increase, slightly } \\
\text { perceptible ligament }\end{array}$ \\
\hline & 4 & $\begin{array}{l}\text { Significant - the patellar ligament is not } \\
\text { palpated }\end{array}$ \\
\hline
\end{tabular}

Table-3. Scoring system for evaluation of hindlimb use in dogs with OA (Budsberg et al., 1999).

\begin{tabular}{|c|c|c|}
\hline Parameter & Score & Clinical sign \\
\hline \multirow[t]{5}{*}{ Lameness } & 1 & Stands and walks normally \\
\hline & 2 & Stands normally, slightly lame at walk \\
\hline & 3 & Stands normally, severely lame at walk \\
\hline & 4 & Abnormal stance, slightly lame at walk \\
\hline & 5 & Abnormal stance, severely lame at walk \\
\hline \multirow[t]{5}{*}{ Weightbearing } & 1 & Normal at both rest and walk \\
\hline & 2 & Normal at rest, favours affected limb at walk \\
\hline & 3 & Partial at both rest and walk \\
\hline & 4 & Partial at rest, no weightbearing at walk \\
\hline & 5 & No weightbearing at rest and walk \\
\hline \multirow{5}{*}{$\begin{array}{l}\text { Response to } \\
\text { contralateral } \\
\text { limb lift* }\end{array}$} & 1 & Accepts displaced weight \\
\hline & 2 & Mild resistance to displaced weight \\
\hline & 3 & Moderate resistance to displaced weight ${ }^{\star *}$ \\
\hline & 4 & Strong resistance to displaced weight ${ }^{\star * \star}$ \\
\hline & 5 & Refusal to lift the contralateral limb \\
\hline \multirow{5}{*}{$\begin{array}{l}\text { Response to } \\
\text { affected limb } \\
\text { extension }\end{array}$} & 1 & No response \\
\hline & 2 & $\begin{array}{l}\text { Mild response (turning head toward the } \\
\text { affected limb) }\end{array}$ \\
\hline & 3 & Moderate response (withdrawal of affected limb) \\
\hline & 4 & Severe response (vocalization, aggression) \\
\hline & 5 & $\begin{array}{l}\text { Disallows manipulation or palpation of } \\
\text { affected limb }\end{array}$ \\
\hline
\end{tabular}

* response of the affected hindlimb; ** replacement of the contralateral limb in $<10 \mathrm{~s} * * *$ replacement of the contralateral limb in $<5 \mathrm{~s}$

The thigh circumference (TC), the stifle joint circumference (SC) and the range of motion of the stifle joint (ROM) between full flexion and extension were measured in all dogs (Robins, 1990; Millis \& Levine, 1997) with goniometer and a band. The animals were in lateral recumbency, with the studied limb on the top. The thigh circumference was determined in the middle of the thigh, the stifle joint circumference - in $90^{\circ}$ flexion, ROM was measured between the longitudinal axes of the femur through trochanter major and the tibia through maleolus lateralis. All results were compared to the contralateral joint.

Statistical analysis: The results were statistically processed by the non-parametric Friedman and Mann-Whitney tests using statistical software (Statmost for Windows, Datamost Corp., 19941995). Differences were accepted as statistically significant at $\mathrm{p}<0.05$. Relationships between parameters were estimated by the Pearson correlation analysis test.

\section{Results}

The average Grisneaux's score increased statistically significantly at $\mathrm{p}<0.01$ from 61 points in the beginning of the experiment to $14 \pm 2$ (day 30) and 12 \pm 2 (day 60) (Table 4). The 
Table-4. Clinical scores and goniometric parameters in dogs with experimental monoiodoacetate ( MI A) model of stifle joint osteoarthritis ( mean + SEM; $n=6$ ).

\begin{tabular}{|c|c|c|c|c|c|}
\hline \multicolumn{2}{|l|}{ Parameter } & \multicolumn{3}{|c|}{ Days after the first MIA injection } & 105 \\
\hline Grisneaux' score & & $6 \pm 1$ & $14 \pm 2^{* *}$ & $12 \pm 2^{* *}$ & $11 \pm 3$ \\
\hline Cross' score & & $4 \pm 0$ & $13 \pm 1^{* *}$ & $12 \pm 1^{* *}$ & $9 \pm 1^{* *}$ \\
\hline \multirow[t]{2}{*}{ Thigh circumference, $(\mathrm{cm})$} & left & $32 \pm 1$ & $27 \pm 1^{*}$ & $27 \pm 1^{* *}$ & $23 \pm 1^{* *}$ \\
\hline & right & $32 \pm 1$ & $32 \pm 1 \#$ & $30 \pm 1 \#$ & $30 \pm 1 \# \#$ \\
\hline Stifle joint circumference, $(\mathrm{cm})$ & left & $25 \pm 1$ & $27 \pm 1$ & $26 \pm 1$ & $25 \pm 1$ \\
\hline
\end{tabular}

$* \mathrm{p}<0.05 ; * * \mathrm{p}<0.01$ vs baseline (day 0$) ;{ }^{*} \mathrm{p}<0.05 ;{ }^{\# *} \mathrm{p}<0.01$ between left $(\mathrm{OA})$ and right (control) joints

Table-5. Correlation coefficients between clinical and goniometric parameters in dogs with experimental monoiodoacetate model of osteoarthritis

\begin{tabular}{|c|c|c|c|c|c|c|}
\hline & GSC & CSc & BSC & TCir & SCir & ROM \\
\hline $\begin{array}{l}\text { GSc } \\
\text { Csc } \\
\text { Bsc } \\
\text { Tcir } \\
\text { Scir } \\
\text { ROM }\end{array}$ & $\begin{array}{l}r=0.88 p<0.001 \\
r=0.83 p<0.001 \\
r=-0.27 \\
r=-0.61 p<0.001 \\
r=0.30 p<0.01\end{array}$ & $\begin{array}{l}r=0.88 p<0.001 \\
---- \\
r=0.92^{* * *} \\
r=-0.37^{* * *} \\
r=-0.63^{* * *} \\
r=0.26\end{array}$ & $\begin{array}{l}r=0.83 p<0.001 \\
r=0.92 p<0.001 \\
-r=-0.32^{* *} \\
r=-0.61^{* * *} \\
r=0.33^{* * *}\end{array}$ & $\begin{array}{l}r=-0.27 \\
r=-0.37 p<0.001 \\
r=-0.32 p<0.01 \\
--- \\
r=0.36 p<0.001 \\
r=0.46 p<0.001\end{array}$ & $\begin{array}{l}r=-0.61 p<0.001 \\
r=-0.63 p<0.001 \\
r=-0.61 p<0.001 \\
r=0.36 p<0.001 \\
-r=-0.33 p<0.001\end{array}$ & $\begin{array}{l}r=0.30 p<0.001 \\
r=0.25 \\
r=0.33 p<0.001 \\
r=0.46 p<0.001 \\
r=-0.33 p<0.001 \\
----\end{array}$ \\
\hline
\end{tabular}

GSc - clinical score according to Grisneaux et al. (1999); CSc - clinical score according to Cross et al. (1997); BSc - clinical score according to Budsberg et al. (1999); TCir - thigh circumference; SCir - stifle joint circumference; ROM - range of motion.

respective score according to Cross et al. yielded $4 \pm 0$ points (day 0$), 13 \pm 1$ (day 30$), 12 \pm 1$ (day 60 ) and $9 \pm 1$ (day 105) $(\mathrm{p}<0.01$ vs baseline). Average Budsberg score before the first MIA administration was $4 \pm 0$ with considerable increase by day 30 to $17 \pm 1$, followed by reduction to $13 \pm 1$ and $11 \pm 1$ by days 60 and $10 \pm 5$, respectively $(\mathrm{p}<0.01$ vs day 0$)$. A strong positive correlation was observed between scores obtained by the three systems (Table 5).

Goniometric analysis provided evidence for thigh muscles atrophy of the left hindlimb (Table 4 ) as thigh circumference decreased significantly from $32 \pm 1 \mathrm{~cm}$ in the beginning to $23 \pm 1 \mathrm{~cm}$ by the $105^{\text {th }}$ day $(\mathrm{p}<0.01)$. The values between left and right limb were also statistically significantly different $(p<0.05$ by days 30 and 60 and $p<0.01$ by day 105). The stifle joint circumference did not show significant differences with time. The range of motion (ROM) of left joints decreased considerably from $115 \pm 2$ in the beginning to $95 \pm 7,91 \pm 2$, and $83 \pm 4$ by days 30,60 and 105 , respectively $(\mathrm{p}<0.01)$. ROM of the left joint exhibited a negative correlation with clinical scores: $\mathrm{r}=-0.61, \mathrm{p}<0.001$ with Grisneaux's and
Budsberg's scores; $\mathrm{r}=-0.63, \mathrm{p}<0.001$ with Cross' score. The same relationships were observed for thigh and joint circumferences (Table 5).

\section{Discussion}

The obtained results showed that OA in dogs could be successfully reproduced by intraarticular injection of the glycolysis inhibitor sodium monoiodoacetate in higher doses and multiple applications unlike Stobie et al. (1994), which did not manage to induce OA with $0.5 \mathrm{mg} / \mathrm{kg}$ and $0.375 \mathrm{mg} / \mathrm{kg}$ MIA in this animal species. According to Beyreuther et al. (2007), a single low MIA dose results only in transient synovitis, resolving by the $14^{\text {th }}$ day. Our experiments evidenced that higher and repeated doses (5-10 $\mathrm{mg} / \mathrm{kg}$ ) succeeded to reproduced all symptoms of osteoarthritis: acute inflammation at onset, progressive degeneration, transition to chronic atrophic phase, similarly to conclusions of Guinamp et al. (1997), that only a sufficient amount of MIA resulted in rapid decline in the locomotor function of rat stifles and that low doses provoked a transient effect. Bove et al. (2003) demonstrated a relationship between the 
locomotor impairment in rats, MIA concentrations and the cumulative effect occurring with time.

Animal behaviour trials showed that joint pain and allodynamic were commonly observed after experimentally induced OA and therefore, they were recommended for OA pain assessment (Bove, 2006). They are even more appropriate for chemical OA model, as the one used in the present study, because the joint instability obtained after the mechanical models could be ruled out as a cause for occurring kinematic changes.

Since the structural integrity of cartilage relies on the normal functioning of chondrocytes, intra-articular injection with MIA produces cartilage degeneration and subchondral bone disorders corresponding to histopathology of OA. As this degenerative model progresses, the subchondral bone becomes exposed joint impairment and mechanical hypersensitivity associated with pain are generated (Harvey and Dickenson, 2009) The pain-related behaviour in this model is thought to be characterised by an early acute inflammatory phase resulting from a fluid expansion of the synovial membrane followed by a persistent phase where the inflammation is largely resolved and is not thought to contribute to the pain pathogenesis (Bove, 2003).

In order to minimize the subjectivity of clinical examination, we have used three pain and gait scoring systems in dogs (Grisneaux et al. 1999; Cross et al., 1997, Budsberg et al., 1999) including numerous different parameters. The observed strong positive correlation between individual scores confirmed the opinion of Gardner (1994), that clinical symptoms in the course of OA development were consistent.

The used goniometric analysis provided an objective measure of the presence of early joint effusion and progressing inactivity and muscle atrophy of treated limb, combined with limited joint motility, specific for this chemical model as early as the first month.

The used experimental model of OA provoking metabolic disorders in articular cartilage exhibited a time course similar to that of naturally occurring disease in dogs, confirmed by clinical scores, goniometric data and the correlation between them.

\section{Acknowledgements}

Many thanks to the team of the Small Animal Clinic at the Faculty of Veterinary Medicine, Stara Zagora for their assistance in performing the experiments.

\section{Conflict of interest}

Authors declare that they have no conflict of interest.

\section{References}

1. Anderson J. (2011). The Stifle. Surgical anatomy. Approaches to the stifle. Specific conditions affecting the stifle joint. In: Houlton J. and Collinson R. Editors. Manual of Small Animal Arthrology, BSAVA, ch. 16:267-280.

2. Bendele A. (2001) Animal models of osteoarthritis. J Musculoskel Neuron Interact, 1(4):363-376.

3. Bennett D. (1990). Diagnosis of joint disease. Joints and joint diseases. In: Whittick W. Editor. Canine Orthopedics, second edition, section 4, ch. 24, 761-833.

4. Beyreuther B., Callizot N., Stohr T. (2007). Antinociceptive efficacy of lacosamide in the monosodium iodoacetate rat model for osteoarthritis pain. Arthritis Research \& Therapy, 9:R14 (doi:10.1186/ar2121).

5. Bohanon T. (1995). Chemical fusion of the distal tarsal joints with sodium monoiodoacetate in horses clinically affected with osteoarthritis. Proc Am Assoc Equine Pract. 41:148-149.

6. Boileau C., Martel-Pelletier J., Guevremont M., Pelletier J-P., Poirier F., Reboul P. (2004). Galectin-3 in osteoarthritis: from a protective to a destructive role. Arthritis Res Ther., 6 (Supl 3):20.

7. Bove SE, Calcaterra SL, Brooker RM, Huber CM, Guzman RE, Juneau PL, Schrier DJ, Kilgore KS (2003). Weight bearing as a measure of disease progression and efficacy of antiinflammatory compounds in a model of monosodium iodoacetate-induced osteoarthritis. Osteoarthr. Cartilage, 11(11):821-830.

8. Bove SE, Laemont KD, Brooker RM, Osborn MN, Sanchez BM, Guzman RE, Hook KE, Juneau PL, Connor JR, Kilgore KS. (2006). Surgically induced osteoarthritis in the rat results in the development of both osteoarthritis 
like joint pain and secondary hyperalgesia. Osteoarthr. Cartilage, 14:1041-1048.

9. Brandt K. (2002). Animal models of osteoarthritis. Biorheology, 39 (1-2):221-235.

10. Budsberg S., Jonston S., Schwarz P., DeCamp C., Claxton R. (1999). Efficacy of Etodolac for the treatment of osteoarthritis of the hip joints in dogs. JAVMA, 214 (2):206-210.

11. Budsberg S., Thomas M. (2006). Advanced diagnostic techniques. In: Houlton J., Cook J., Innes J., Langley-Hobbs S., Brown G. Editors. BSAVA Manual of Canine and Feline Musculoskeletal Disorders. Glochester, England, ch 4:27-33.

12. Carlson C., Loeser R., Jayo M., Weaver D., Adams M., Jerome C. (2005). Osteoarthritis in cynomolgus macaques: a primate model of naturally occurring disease. J Orthop Res., 12(3):331-339.

13. Combe R., Bramwell S., Field M. (2004). The monosodium iodoacetate model of osteoarthritis: a model of chronic nociceptive pain in rats? Nociceptive Letters., 370 (2-3):236-240.

14. Crook T., McGowan C., Pead M. (2007). Effect of passive streching on the range of motion of osteoarthritic joints in 10 labrador retrivers. Vet Record., 160:545-547.

15. Cross A., Budsberg S., Keefe T. (1997). Kinetic gait analysis assessment of Meloxicam efficacy in a sodium urate-induced synovitis model in dog. AJVR, 58 (6):626-631.

16. Ehrlich G. (2003). The rise of Osteoarthritis. Bull. of the World Health Organization., 81(9): 630.

17. Gardner D. (1994). Problems and paradigms in joint pathology. JAnat., 184:465-576.

18. Gencosmanoglu B., Eryavuz M., Dervisoglu S. (2001). Effects of some Nonsteroidal antiinflammatory drugs on articilar cartilage of rats in an experimental model of osteoarthritis. Res Exp Med(Berl)., 200(3):215-226.

19. Grainger R., Cicuttini F. (2004). Medical management of osteoarthritis of the knee and hip joints. MJA, 180 (3):232-236.

20. Grisneaux E., Pibarot P., Dupus J., Blais D. (1999). Comparison of Ketoprofen and caprofen administrated prior to orthopedic surgery for control of postoperative pain in Dogs. JAVMA, 215 (8):1105-1110.

21. Guinamp C., Gegout-Pottie P., Phillipe L., Terlain B., Netter P., Gillet P. (1997). Mono iodoacetateinduced experimental osteoarthritis:a dose- response study of loss of mobility, morphology, and biochemistry. Arthritis Rheum.,40(9):16701679.

22. Gustafson S., TrotterG., Norrdin R., Wrigley F., Lamar C. (1992). Evaluation of intra-articularly administreted sodium monoiodoacetateinduced chemical injury to articular cartilage of horses. Am J Vet Res., 53(7):1193-1202.

23. Guzman R., Evans M., Bove S., Morenko B., Kilgore K. (2003). Mono-Iodoacetate-Induced histologic changes in subchondral bone and articular cartilage of rat femorotibial joints: An animal model of osteoarthritis. Toxicol.Pathol., 31:619-624.

24. Haima P. (2005). Biochemical markers for the management of rheumatoid arthritis and osteoarthritis. Osteomedical group. Clinical \& technical monograph., 1-28.

25. Harvey V. L. and Dickenson A. H. (2009). Behavioural and electrophysiological characterisation of experimentally induced osteoarthritis and neuropathy in C57Bl/6 mice. Molecular Pain., 5: 18.

26. Horn V., Papousek F., Havelka S. (1988). Experimental arthrosis caused by chemical cartilage damage. Z Orthop Ihre Grenzgeb., 126(1):71-75.

27. Jaegger G., Marcellin-Little D., Levine D. (2002). Reliability of goniometry in Labrador Retrievers. Am J Vet Res., 63:979-986.

28. Janusz M., Hookfin S., Heimeyer S., Woessner J., Freemont A., Hoyland J. (2001). Moderation of iodoacetate-induced experimental osteoarthritis in rats by matrix metalloproteinase inhibitors. Osteoarthr. Cartilage., 9(8):751-760.

29. Kalbhen D. (1987). Chemical model of osteoarthritis- a pharmacological evaluation. Rheumatology., 14:130-131.

30. Kalbhen D., Jansen G. (1990). Pharmacological studies on the antidegeneratine effect of ademetionine in experimental arthritis in animals. Arzneimittelforschung., 40(9):10171021.

31. Kalbhen DA, Blum U. (1977). Theoretisches Konzept und experimentelle Bestätigung für ein Arthrosemodell am Versuchstier. Arzneimittel forschung., 27:527-531.

32. Lipowitz A. and Newton C. (1985). Degenerative joint disease and Traumatic arthritis. In: Textbook of Small Animal Orthopaedics by Newton C. and Nunamaker D., Ithaca, New York, USA, www.ivis.org.books. 
33. Lipowitz A. (1993). Degenerative joint disease. Musculoskeletal system, sec.15. In: Textbook of small animal surgery, by Douglas Slatter, vol. II; second ed., Philadelphia, USA, ch. 143:1921-1927.

34. May S. (1994). The diagnosis of degenerative joint disease. Degenerative joint disease (osteoarthritis, osteoarthrosis, secondary joint disease). In: Manual of small animal arthrology by Houlton J. and Collinson R., BSAVA, ch 5: 62-73.

35. Millis D., Levine D. (1997). The role of exercise and physical modalities in the treatment of osteoarthritis. Vet Clin North Am., 27 (4):913930.

36. Murray R. (2002). Animal models for orthopaedic Disease- Who benefits? The Vet Journal, 163:230-231.

37. Penraat J., Allen A., Fretz P., Bailey J. (2000). An evaluation of chemical arthrodesis of the proximal interphalangeal joint in the horse by using monoiodoacetate. The Can. J Vet Res., 64:212-221.

38. Regling G., Buntrock P., Geiss W., Lindenhayn K.(1989). Monoiodoacetic acid-induced arthropathy of the rabbit knee- a contribution to the pathogenesis of arthrosis. Beitr Orthop Traumatol., 36(5):193-203.

39. Robins G. (1990). The canine stifle joint. In: Canine orthopedics by Wiliam G. Whittick, section VI: Joint disorders, ch. 23:693-760.

40. Saied A., Cherin E., Gaucher H., Laugier P.,
Gillet P., Floquet J., Netter P., Berger G. (1997). Assessment of articular cartilage and subchondral bone: Subtle and progressive changes in experimental osteoarthritis using 50 $\mathrm{MHz}$ echography in vitro. J Bone Miner Res., 12:1378-1386.

41. Schaller S., Henriksen K., Hoegh-Andersen P., Sondergaard B., Sumer E., Tanko L., Qvist P., Karsdal M. (2005). In vitro, ex vivo, and in vivo methodological approaches for studying therapeutic targets of osteoporosis and degenerative joint diseases: How biomarkers can assist? ASSAY and Drug Development Technologies., 3 (5):553-580.

42. Stobie D., Lipowitz A., Greer N. (1994). Failure of monoiodoacetate to induce lameness in Dogs. V.C.O.T., 7:91-93.

43. Tirgari M., Vaghan L. (1975). Arthritis of the canine stifle joint. The Vet Record., 96(18):394399.

44. Van der Kraan P., Vitters E., Van der Putte L., Van der Berg W. (1989). Development of osteoarthritic lesions in mice by metabolic and mechanical altrations in the knee joints. Am J Pathol.,35: 1001-1014.

45. Vasseur P. (1993). Stifle joint. In: Textbook of Small Animal Surgery by D. Slatter, sec.ed., vol.II, ch.137:1817-1862.

46. Witter J. (1999). Osteoarthritis (OA): in vitro and animal models. In: Draft guidnes for OA. Conceptual model of human OA.,www.fda.gov/ cder/guidance. 